\title{
A CASE OF VESICOCERVICAL FISTULA
}

\author{
SAHA MR ${ }^{1}$, BEGUM M ${ }^{2}$, CHOWDHURY MSA ${ }^{3}$, ARA I ${ }^{4}$
}

\begin{abstract}
:
Vesicocervial fistula is still prevailing in developing countries. It is mostly due to a result of vaginal delivery following obstructed/prolonged labour especially in rural areas. A vesicocervical fistula causes mental and physical distress to a patient very often resulting in her being a social outcast. Surgery has so far been the gold standard of treatment for this condition. A 43 years old lady, para 6, of which 4 are dead and 2 living, came from Faridpur, was admitted into Dhaka Medical College Hospital with the complaints of urinary in continence for 15 years since her last birth. The methylne blue dye test revealed that the urine was exiting through the cervical canal and an old big tear about $3 \mathrm{~cm} \times 4 \mathrm{~cm}$ was found on anterior wall of the cervix and vagina, through which the dye came out. Intravenous urography performed later showing normal study. She was diagnosed as a case of vesicocervical fistula. Ultrasonography of whole abdomen revealed fibroid uterus. The patient underwent an operation of total abdominal hysterectomy with repair of urinary bladder.
\end{abstract}

Key words: Vesicocervial fistula, vaginal delivery, urinary incontinence.

J Dhaka Med Coll. 2012; 21(2) : 226-228.

\section{Introduction}

Vesicocervial fistula is a disease that is rare in developed world but still prevailing in developing countries. It is mostly due to a result of obstetrical cause, sometimes a gynaecological operation may lead to the condition. ${ }^{1,2}$ This study reports our experience of such a case. This consequence of child delivery, secondary to a lesion in the bladder, was followed with a distressing, long-lasting urinary incontinence, which is non-reactive to conservative treatment. Here, the case details, clinical features, possible causes and treatment modality are discussed.

\section{Case Report}

A 43 years old lady, para 6, of which 4 are dead and 2 living, came from Faridpur, was admitted in to Dhaka Medical College Hospital with the complaints of urinary in continence for 15 years since her last birth. The patient states that she has been married for 28 years. Her first, second and third children were delivered at home by vaginal route. Her third child died at the age of 3 months due to pneumonia. Her fourth baby was delivered at home by local 'dai' (birth attendant) after 15-16 hours of obstructed labour. She noticed dribbling of urine following the delivery of a dead baby. Since then she has no desire to pass urine and has been suffering from vulval itching. As she did not know the condition, she has never sought for any medical attention. After hearing the treatment facility of the problem is available at Dhaka Medical College Hospital from a rural neighbourhood, she got herself admitted on April 05, 2011.

On examination, her general condition was good and she had leakage of urine through the vagina. She is non-asthmatic, nonhypertensive and non-diabetic. The methylne blue dye test revealed that the urine was exiting through the cervical canal and an old big tear about $3 \mathrm{~cm} \times 4 \mathrm{~cm}$ was found on anterior wall of the cervix and vagina, through which the dye came out. Intravenous urography

1. Dr. Mukti Rani Saha, Resident Surgeon, Department of Obstetrics \& Gynaecology, Dhaka Medical College Hospital, Dhaka.

2. Dr. Masuda Begum, Associate Professor, Department of Obstetrics \& Gynaecology, Dhaka Medical College, Dhaka.

3. Dr. Md. Shafiqul Alam Chowdhury, Assistant Professor of Urology, Dhaka Medial College, Dhaka.

4. Dr. Iffat Ara, Professor, Department of Obstetrics \& Gynaecology, Dhaka Medical College, Dhaka

Correspondence: Dr. Mukti Rani Saha, Resident Surgeon, Department of Obstetrics \& Gynaecology, Dhaka Medical College Hospital, Dhaka. 
performed later showing normal study. She was diagnosed as a case of vesicocervical fistula. She received antibiotic tablet cefuroxine 500 $\mathrm{mg}$ for the treatment of urinary tract infection, tablet vitamin-B complex and vitamin-C, Iron supplement and anti-helminthic prior to operation. Necessary preoperative assessments were done, including ultrasonography of whole abdomen, where fibroid uterus was diagnosed as well. Injection tetanus toxoid was given IM. Finally, she underwent an operation of total abdominal hysterectomy with repair of urinary bladder on April 9, 2011.

\section{Operative Procedure}

With all asceptic precaution, the abdomen was opened. Total abdominal hysterectomy was done after retraction of the urinary bladder. The bladder was repaired in three layers using 3-0 vicryl sutures on the inner layer in a continuous fashion, beginning at the apex and extending through the full muscle layers. The first layer was burried with a second layer using interrupted 1-0 vicryl sutures. Transabdominal ureteral and urethral catheterizations were performed.

The postoperative period was uneventful. The ureteric catheter was removed on $7^{\text {th }}$ post operative day and the perurethral catheter was removed on $21^{\text {st }}$ post operative day. The patient was discharged on $24^{\text {th }}$ post operative day.

\section{Discussion}

Urinary incontinence is a common health problem among middle aged women ${ }^{1,3}$. In contrast, vesicocervical fistula is an extremely uncommon complication occurring only in 1$4 \%$ of all urogenital fistulas, which are seen in only $0.1-1.5 \%$ after gynecologic operation ${ }^{3}$, but it is still frequently found in developing countries ${ }^{4}$. A vesicovaginal fistula or vesicocervical fistula causes mental and physical distress to a patient very often resulting in her being a social outcast. Surgery has so far been the gold standard of treatment for this condition but there is a failure rate also $^{3}$. Most vesicocervical fistulas are complications of caesarean section with symptoms of urinary incontinence ${ }^{3,5,6}$ Other possible causes include rupture of the lower uterine segment and bladder due to a traumatic forceps delivery, tuberculosis of the bladder and a perforation of an intrauterine contraceptive device into the bladder ${ }^{1,3}$. Primary etiology of the fistula in this presented case was an inadvertent iatrogenic laceration to the cervix including bladder. The obstructed labour of Halima during the birth causes big tear necrosis of the vagina and bladder wall and also surrounding the tear region. The dead cells and vessels were sloughed out with the period of time due to necrosis leading to the bigger size of communicating fistula.

The presentation of a vesicouterine or vesicocervical fistula would largely depend on its location which may be above or below the isthmus of the uterus. This is because of a functional sphincter at the isthmus as demonstrated by Westman and Yopussef in mid-twentieth centuries through transabdominal, intra-uterine insufflation and manometric hysterography procedures ${ }^{7}$. Transabdominal repair of the fistula is recommended in such conditions, but the procedure is done comparatively, less than the vaginal route repair ${ }^{8,9}$. Atypical presentation of more fibrosis and distortion of such fistulas may considerably delay the diagnosis. In contrast to vesicovaginal fistula, conservative management may be tried in selected cases ${ }^{10}$. Our case of distressing vesicocervical fistula was successfully repaired and the patient was discharged.

\section{Conclusion}

In their work describing the complications of obstructed labor, Arrowsmith, Hamlin and Wall ${ }^{11}$ stated that "obstructed labor is one of the greatest unaddressed healthcare needs for the women of this planet. It should not be allowed to remain so." One must realize the historical context of the obstetric fistula and the societal difficulties surrounding the prevailing problem and the surgical principles that govern fistula repair. Successful closure of vesicocervical fistula requires accurate diagnostic evaluation, appropriate repair using techniques that utilize basic surgical principles, and the careful application of 
interposing tissue flaps. With a better understanding of the issue along with experience, we could begin to combat the problem and work to improve the healthcare status of women around the world. In this case, abdominal hysterectomy was done due to fibroid uterus and also the surrounding area of the tear is distorted and fibrosed and the patient was amenorrhoeic due to repeated infection.

\section{References:}

1. Khan RM, Raza N, Jehanzaib M, Sultan R. Vesicovaginal fistula: an experience of 30 Cases at Ayub Teaching Hospital Abbottabad. J Ayub Med Coll Abbottabad 2005; 17: 48-50.

2. Wandschneider G. Vesicocervical fistula. [Abstract]. Geburtshilfe Frauenheilkd 1985; 45: 895-7.

3. Dudderidge TJ, Haynes SV, Davies AJ, Jarmulowicz M, Al-Akraa MA. Vesicocervical fistula: rare complication of cesarean section demonstrated by magnetic resonance imaging. Urology 2005; 65: 174.

4. Evans LA, Ferguson KH, Foley JP, Rosanshi TA, Morey AF, Fibrin sealant for the management of genitourinary injuries, fistulas and surgical complications. J Urol 2003; 169: 1360-2.
5. Kapur K, Rana P. Vesicovaginal fistula: a new treatment modality. Armed Forces Med J India 2007; 63: 69-70.

6. Rant V, Bhattacharye M. Vesical fistula: an experience for a developing country. J Postgrad Med 1993; 39: 20-1.

7. Varawalla NY, Krishna UR. Conservative management of traumatic vesico-cervical fistula (a case report). J Postgrad Med 1987; 33: 102-4.

8. Kapoor R, Ansari MS, Singh P, Gupta P, Khurana $\mathrm{N}$, Mandhani A, et al. Management of vesicovaginal fistula: an experience of 52 cases with a rationalized algorithm for choosing the transvaginal or transabdominal approach. Indian J Urol 2007; 23: 372-6.

9. Shah SJ. Laparoscopic transabdominal transvesical vesicovaginal fistula repair. J Endourol 2009; 23: 1135-7.

10. Al-Rifaei M, El-Salmy S, Al-Rifaei A, Salama A. Vesicouterine fistula-variable clinical presentation. Scand J Uro Nephrol 1996; 30: 287-9.

11. Arrowsmit S, Hamlin EC, Wall LL. Obstructed labor injury complex: obstetric fistula formation and the multifaceted morbidity of maternal birth trauma in the developing world. Obstet Gynecol Surg 1995; 51: 568-74. 